\title{
Characterization of Gnomoniopsis idaeicola, the Causal Agent of Canker and Wilting of Blackberry in Serbia
}

\author{
Miloš Stevanović, Danijela Ristić, Svetlana Živković, and Goran Aleksić, Department of Plant Diseases, Institute for Plant Protection and \\ Environment, 11000 Belgrade, Serbia; and Ivana Stanković, Branka Krstić, and Aleksandra Bulajić, ${ }^{\dagger}$ Institute of Phytomedicine, Depart- \\ ment of Phytopathology, University of Belgrade - Faculty of Agriculture, 11080 Belgrade, Serbia
}

\begin{abstract}
Blackberry cane diseases with the symptoms of necrosis, canker, and wilting are caused by several fungi worldwide. Surveys conducted from 2013 to 2016 in Serbia revealed the occurrence of Gnomoniopsis idaeicola, the causal agent of cane canker and wilting, which was found to be distributed in almost half of the surveyed orchards, in three blackberry cultivars, and with disease incidence of up to $80 \%$. Wide distribution and high disease incidence suggest that $G$. idaeicola has been present in Serbia for some time. Out of 427 samples, a total of 65 G. idaeicola isolates were obtained (isolation rate of $34.19 \%$ ). Reference isolates, originating from different localities, were conventionally and molecularly identified and characterized. G. idaeicola was detected in single and mixed infections with fungi from genera Paraconiothyrium,

Colletotrichum, Diaporthe, Botryosphaeria, Botrytis, Septoria, Neofusicoccum, and Discostroma, and no diagnostically specific symptoms could be related directly to the G. idaeicola infection. In orchards solely infected with $G$. idaeicola, blackberry plant mortality was up to $40 \%$, and yield loses were estimated at 50\%. G. idaeicola isolates included in this study demonstrated intraspecies diversity in morphological, biological, pathogenic, and molecular features, which indicates that population in Serbia may be of different origin. This is the first record of a massive outbreak of G. idaeicola infection, illustrating its capability of harmful influence on blackberry production. This study represents the initial step in studying G. idaeicola as a new blackberry pathogen in Serbia, aiming at developing efficient control measures.
\end{abstract}

Blackberries (Rubus L. subgenus Rubus Watson) have long been readily consumed wild fruits, known to be rich in anthocyanins and antioxidants, with beneficial effects on human health and the immune system (Pellegrini et al. 2003; Reyes-Carmona et al. 2005). The first commercial blackberry cultivars were introduced in the mid-1980s in the United States, and modern cultivars are mainly hybrids derived from two or more species, including European blackberry, Rubus fruticosus L. (=R. plicatus Weihe \& Nees), as well as $R$. laciniatus Willdenow, $R$. procerus $\mathrm{P}$. J. Muell., $R$. allegheniensis Porter, $R$. argutus Link., and $R$. trivales Michaux (Clark and Finn 2011). As for the plant architecture, blackberry cultivars are usually described as erect, semierect, and trailing and almost all are characterized by having perennial roots and crowns and biennial canes. In the first year, canes are vegetative (primocanes), and they enter reproductive stage (floricane) the next spring, producing short lateral branches on which flowers and fruits are formed (Strik et al. 2007).

The world production of blackberries is organized on approximately 20,000 ha, with Europe being the world's largest producer (Strik et al. 2007). Serbia is the fourth largest producer in the world (Strik et al. 2007), with blackberry grown on around 5,300 ha in several regions with suitable climate conditions (Nikolić and Milivojević 2015) and participating in the world's annual production with approximately 18\% (Strik et al. 2007). Numerous blackberry cultivars are commercially available worldwide. Semierect cultivar Čačanska bestrna, which is popular and well accepted by the growers in Serbia (Nikolić and Milivojević 2015), is currently grown on more than $5 \%$ of blackberry production area in the world (Strik et al. 2007).

Fungal family Gnomoniaceae (Diaporthales, Sordariomycetes, Sordariomycetidae) is morphologically and molecularly wellestablished (Castlebury et al. 2002) and comprises the well-studied

${ }^{\dagger}$ Corresponding author: A. Bulajić; E-mail: bulajicaleksandra@yahoo.com

Funding: This research was financially supported by the Ministry of Education, Science and Technological Development of the Republic of Serbia (grants TR 31018 and III-43001).

Accepted for publication 29 July 2018.

C 2019 The American Phytopathological Society genus Gnomonia and seven additional segregated genera, including Gnomoniopsis (Sogonov et al. 2008). Some members of the Gnomoniaceae family are well-known plant pathogens (Rossman et al. 2007), but some of them are commonly present as endophytes on the leaves and overwintering plant organs (Danti et al. 2002). The genus Gnomoniopsis currently contains 13 recognized species (Walker et al. 2010), including several economically important pathogens of plants mainly belonging to the families Rosaceae, Fagaceae, and Tiliaceae (Sogonov et al. 2008).

Apart from Gnomoniopsis idaeicola (P. Karst.) D.M. Walker, there are at least 21 different fungal species that cause cane and foliar diseases of blackberry, excluding rusts, as well as 16 additional pathogenic fungi that cause root and crown diseases described worldwide (Martin et al. 2017). The first data on G. idaeicola (initially referred to as Calosphaeria idaeicola P. Karst.) originate from 1886, when the holotype was collected on raspberry (Rubus idaeus L.) in Finland. Subsequent isolations were recorded in 2008 from Rubus sp. (France and United States [California]), $R$. armeniacus Focke (United States [Oregon and Washington]), and $R$. pedatus Banks \& Sol. ex Lowe (United States [Oregon]) (Walker et al. 2010) and in 2011 in Australia (Cunnington et al. 2011). In Iran, Mirhosseini et al. (2015) isolated Gnomoniopsis sp., which caused leaf spots on $R$. fruticosus and, on the basis of its morphology and internal transcribed spacer (ITS) sequencing, designated it as probably $G$. idaeicola. Although $G$. idaeicola has been described as having a narrow host range, limited to Rubus spp. (Walker et al. 2010), there are some unpublished data on its isolation from Actinidia deliciosa in New Zealand (A. Bulajić, personal communication), wheat in France (Comby et al. 2016), and Myrtus communis in Spain (Vaz 2012), but with no trace data on how the identification was performed and if pathogenicity was confirmed. Considering that the number of G. idaeicola isolates described and characterized so far is limited, its epidemiology may only be deduced from a broad range of common characteristics described for the Gnomoniopsis spp. (Sogonov et al. 2008; Walker et al. 2010).

In Serbia, the presence of several fungi that cause blackberry cane diseases, including Gnomonia rostellata (Fries) Wehmeyer (Arsenijević and Veselić 1995), Seimatosporium lichenicola (Fuckel) Shoemaker \& E. Muller (Arsenijević et al. 1999), Phomopsis sp. (Arsenijević 2005), Septocyta ruborum (Lib.) Petr., Didymella applanata (Niessl) Sacc. (Arsenijević 2006a), Botryosphaeria dothidea (Moug.: Fr.) Cesati \& De Notaris, B. obtusa (Schwein.) 
Shoemaker, Coniothyrium fuckelii Saccardo, and Sphaceloma necator (Ellis \& Everhart) Jenkins \& Shear (Arsenijević 2006b), have been reported so far. Owing to the upward trend of blackberry production level in Serbia, cane diseases have become widely spread in certain production regions, causing significant yield reductions (Nikolić and Milivojević 2015). Currently available data on fungi that cause blackberry cane diseases in Serbia are limited, mainly out of date or based on only symptomatology and conventional identification.

In this paper we report the first results of the 4-year study of blackberry cane diseases in Serbia and the occurrence of G. idaeicola, the causal agent of cane canker and wilting. The main objectives of this study were (i) to determine distribution and incidence of G. idaeicola, (ii) to investigate symptomatology and morphological and pathogenic variability of Serbian isolates originating from different blackberry production regions, and (iii) to establish relationships among Serbian isolates and their position within the genus Gnomoniopsis by sequencing of four genetic markers of ribosomal DNA and protein coding regions, including $\beta$-tubulin, tef- $1 \alpha$ (translation elongation factor $1 \alpha$ ), FG1093 gene (60S ribosomal protein L37), and the ITS region (ITS1, 5.8S rDNA, and ITS2 regions).

\section{Materials and Methods}

Sampling and isolate collection. To determine the presence and distribution of G. idaeicola in Serbia, a 4-year survey of blackberry cane diseases was conducted in 2013 to 2016. Field inspection and collection of samples were performed in March and April of each year. A total of 24 fields of blackberry crops were surveyed at 20 localities in 13 administrative districts of major production areas. A total of 427 samples were collected, including overwintering blackberry canes with the symptoms of canker and bark necrosis. The survey included the five most commonly grown blackberry cultivars in Serbia: Čačanska bestrna, Loch Ness, Thornfree, Chester Thornless, and Triple Crown, commercially grown in 16, 4, 2, 1, and 1 orchards, respectively. Inspected orchards were of different sizes ( 0.03 to $1.6 \mathrm{ha})$ and of different ages ( 2 to 15 years). Before sampling, the disease incidence was estimated by randomly counting and rating 100 plants after zigzag walking throughout the orchards. Different numbers of samples (5 to 30) were collected from each orchard, depending on its size and types of symptoms. Each sample consisted of two symptomatic canes from one plant. Sampled canes were cut into 30 - to $40-\mathrm{cm}-$ long fragments, sealed in plastic bags, stored at $5^{\circ} \mathrm{C}$, and processed within $24 \mathrm{~h}$ after being brought to the laboratory.

Two 5-cm-long fragments were cut off from each sampled cane, washed with tap water for $2 \mathrm{~h}$, and surface sterilized for 2 min with commercial bleach ( $0.5 \%$ sodium hypochlorite). Four small pieces from different parts of the border between necrotic and healthy tissue of each fragment (16 per sample) were aseptically excised, air dried for $30 \mathrm{~min}$, and placed on potato dextrose agar (PDA; $200 \mathrm{~g}$ of potato, $20 \mathrm{~g}$ of dextrose, $17 \mathrm{~g}$ of agar, and 1 liter of distilled $\mathrm{H}_{2} \mathrm{O}$ ). Plates were incubated at $24^{\circ} \mathrm{C}$ for 5 days, and developed colonies were transferred onto fresh PDA. Pure cultures of fungal isolates obtained from each sample were grouped according to colony appearance and were used for obtaining single-spore isolates. All morphospecies obtained from each sample were preliminarily identified to the genus level according to the morphology and sequencing of the ITS region of rDNA. Isolates of Gnomoniopsis sp., originating from different localities, were maintained on PDA slants at $4^{\circ} \mathrm{C}$ and used for further characterization. The overall isolation frequency and the isolation frequency per field were calculated (Saleemi et al. 2012).

Morphological identification. Eleven single-spore isolates of G. idaeicola, one from each locality, were selected as representative and were used for conventional identification based on macroscopic and microscopic characteristics. Colony appearance, radial growth rate, and conidiomata presence, formation pattern, and abundance were assessed on PDA plates 10, 20, and 40 days postinoculation (dpi), incubated at $24^{\circ} \mathrm{C}$ and a cycle of $12 \mathrm{~h}$ of light $/ 12 \mathrm{~h}$ of darkness. The appearance and formation pattern of perithecia, asci, and ascospores were assessed directly on the overwintered canes of cultivar Cačanska bestrna (locality of Miokus). Isolated conidiomata and perithecia were placed on a glass slide in a drop of sterile water and directly observed using a stereo (EU Instruments SM-2TXX/ 10) or a compound microscope (Olympus CX41), and photos were taken using microscope eyepiece camera (10 MP Aptina Color CMOS, MU1000). In all measurements, an ocular micrometer was used for measuring 50 (conidiomata and perithecia) or 100 (conidia, asci, and ascospores) microstructures per isolate. Colony growth rate was estimated by measuring two perpendicular colony diameters on five plates per isolate and calculating the average value for each isolate. Measurements of all morphological features were analyzed by one-way analysis of variance at the $5 \%$ probability level after testing the normality (Shapiro-Wilk test) and fulfilling the homogeneity assumptions, and the individual pairwise comparisons were made using Tukey's test (Sokal and Rohlf 1995). Data on colony growth were analyzed using the Kruskal-Wallis test because data were not homogeneous. All statistical analyses were performed using XLSTAT software.

DNA amplification and sequencing. Molecular identification and characterization of Serbian isolates were performed by sequencing four selected genomic fragments: nuclear ribosomal ITS region rDNA and protein-coding genes $\beta$-tubulin, tef- $1 \alpha$ (translation elongation factor $1 \alpha$ ), and FG1093 (60 S ribosomal protein L37). Selected genomic fragments were amplified using the following primers: ITS1-F (Gardes and Bruns 1993) and ITS4 (White et al. 1990 ) for the ITS region, T1 and T2 (O'Donnell and Cigelnik 1997) for the $\beta$-tubulin gene, EF1-728F/EF1-1199R and EF1983F/EF1-1567R (Carbone and Kohn 1999; Rehner and Buckley 2005; Walker et al. 2010) for the tef-1 $\alpha$ gene, and FG1093 E1F1/ E3R1 (Walker et al. 2012) for the FG1093 gene (Table 1). Total genomic DNA was extracted from $100 \mathrm{mg}$ of dry mycelium weighed from 10-day-old cultures, using the DNeasy Plant Mini Kit (Qiagen, Hilden, Germany), according to the manufacturer's instructions. Polymerase chain reaction (PCR) was performed in a 2720 Thermal Cycler (Applied Biosystems, Foster City, CA) in a total reaction volume of $25 \mu \mathrm{l}$, consisting of $12.5 \mu \mathrm{l}$ of $2 \times$ PCR Master mix (K071, Fermentas, Lithuania), $9 \mu$ l of RNase-free water, $1.25 \mu$ l of both forward and reverse primers (100 pmol/ $\mu \mathrm{l}$, Metabion International, Planegg/ Steinkirchen, Germany), and $1 \mu$ of template DNA. Amplification conditions were as follows: initial denaturation step of $10 \mathrm{~min}$ at

Table 1. DNA primers used in this study

\begin{tabular}{lll}
\hline Primer name & \multicolumn{1}{c}{ Primer sequence $\left(\mathbf{5}^{\prime} \mathbf{- 3} \mathbf{\prime}\right)$} & References \\
\hline ITS1F & CTTGGTCATTTAGAGGAAGTAA & Gardes and Bruns (1993) \\
ITS4 & TCCTCCGCTTATTGATATGC & White et al. (1990) \\
EF1-728F & CATCGAGAAGTTCGAGAAGG & Carbone and Kohn (1999) \\
EF1-983F & GCYCCYGGHCAYCGTGAYTTYAT & Rehner and Buckley (2005) \\
EF1-1567R & ACHGTRCCRATACCACCRATCTT & Rehner and Buckley (2005) \\
EF1-1199R & GGGAAGTACCMGTGATCATGT & Walker et al. (2010) \\
T1 & AACATGCGTGAGATTGTAAGT & O'Donnell and Cigelnik (1997) \\
T2 & TAGTGACCCTTGGCCCAGTTG & Walker et al. (2012) \\
E1F1 & GCGCCACAMCAAGWCSCACRC \\
\hline
\end{tabular}


$95^{\circ} \mathrm{C}$, followed by 35 cycles of $30 \mathrm{~s}$ at $94^{\circ} \mathrm{C}, 30 \mathrm{~s}$ at $55^{\circ} \mathrm{C}$, and $1 \mathrm{~min}$ at $72^{\circ} \mathrm{C}$, with a final extension period of $10 \mathrm{~min}$ at $72^{\circ} \mathrm{C}$. Amplification conditions for the FG1093 gene were as follows: 2 min at $95^{\circ} \mathrm{C}$, followed by 10 cycles of $1 \mathrm{~min}$ at $95^{\circ} \mathrm{C}, 30 \mathrm{~s}$ at 65 to $55^{\circ} \mathrm{C}$ (decreasing by $1^{\circ} \mathrm{C}$ in each cycle), and $1 \mathrm{~min}$ at $72^{\circ} \mathrm{C}$, followed by 35 cycles of $1 \mathrm{~min}$ at $95^{\circ} \mathrm{C}, 30 \mathrm{~s}$ at $59^{\circ} \mathrm{C}$, and $1 \mathrm{~min}$ at $72^{\circ} \mathrm{C}$. Amplified products were stained with Midori Green DNA Stain (Nippon Genetics), analyzed by $1 \%$ agarose gel electrophoresis, and visualized under an ultraviolet transilluminator.

The PCR products of all genomic regions were sequenced in both directions in an automated sequencer (ABI 3730XL Automatic Sequencer, Macrogen, Seoul, South Korea), using the same primers as for the amplification. Consensus sequences were computed using ClustalW (Thompson et al. 1994), integrated in MEGA6 software

Table 2. Isolates of the Gnomoniopsis spp. and Gnomoniopsis-related species used in this study

\begin{tabular}{|c|c|c|c|c|c|c|c|}
\hline \multirow[b]{2}{*}{ Species } & \multirow[b]{2}{*}{ Strain/isolate } & \multirow[b]{2}{*}{ Host } & \multirow[b]{2}{*}{ Country } & \multicolumn{4}{|c|}{ GenBank accessions } \\
\hline & & & & ITS & $\beta$-tubulin & $t e f-1 \alpha$ & FG1093 \\
\hline Apiognomonia veneta & CBS 342.86 & Platanus acerifolia & France & DQ313531 & $\ldots$ & $\ldots$ & $\ldots$ \\
\hline Gnomoniopsis alderdunense & CBS 125679 & Rubus pedatus & U.S.A. (OR) & GU320826 & $\ldots$ & $\ldots$ & $\ldots$ \\
\hline G. alderdunense & CBS 125680 & R. parviflorus & U.S.A. (OR) & GU320825 & GU320787 & GU320801 & JF274653 \\
\hline G. alderdunense & CBS 125681 & R. parviflorus & U.S.A. (OR) & GU320827 & $\ldots$ & $\ldots$ & $\ldots$ \\
\hline G. chamaemori & CBS 804.79 & R. chamaemorus & Finland & GU320817 & GU320777 & GU320809 & JF274646 \\
\hline G. clavulata & AR 4313; CBS 121255 & Quercus falcata & U.S.A. (MD) & EU254818 & EU219211 & GU320807 & JF274644 \\
\hline G. comari & CBS 806.79 & Comarum palustre & Finland & EU254821 & EU219156 & GU320810 & JF274647 \\
\hline G. comari & CBS 807.79 & C. palustre & Finland & EU254822 & $\ldots$ & $\ldots$ & $\ldots$ \\
\hline G. comari & CBS 809.79 & C. palustre & Switzerland & EU254823 & $\ldots$ & $\ldots$ & $\ldots$ \\
\hline G. fructicola & AR 4275; CBS 121226 & Fragaria vesca & U.S.A. (MD) & EU254824 & $\ldots$ & $\ldots$ & $\ldots$ \\
\hline G. fructicola & CBS 208.34 & Fragaria sp. & France & EU254826 & EU219149 & GU320808 & JF274645 \\
\hline G. fructicola & CBS 125671 & Fragaria sp. & U.S.A. (NJ) & GU320816 & $\ldots$ & $\ldots$ & $\ldots$ \\
\hline G. guttulata & BPI $877452 \mathrm{~A}$ & Agrimonia eupatoria & Bulgaria & EU254812 & $\ldots$ & $\ldots$ & $\ldots$ \\
\hline G. idaeicola & CBS 125672 & Rubus sp. & U.S.A. (CA) & GU320823 & $\ldots$ & $\ldots$ & $\ldots$ \\
\hline G. idaeicola & CBS 125673 & $R$. pedatus & U.S.A. (OR) & GU320824 & $\ldots$ & $\ldots$ & $\ldots$ \\
\hline G. idaeicola & CBS 125674 & Rubus sp. & France & GU320820 & $\ldots$ & $\ldots$ & $\ldots$ \\
\hline G. idaeicola & CBS 125675 & $R$. armeniacus & U.S.A. (OR) & GU320822 & $\ldots$ & $\ldots$ & $\ldots$ \\
\hline G. idaeicola & CBS 125676 & R. armeniacus & U.S.A. (WA) & GU320821 & GU320784 & GU320811 & JF274654 \\
\hline G. idaeicola & V1EG6 & wheat plant & France & KT692597 & $\ldots$ & $\ldots$ & $\ldots$ \\
\hline G. idaeicola & $155 \mathrm{e}$ & Myrtus communis & Spain & КC959208 & $\ldots$ & $\ldots$ & $\ldots$ \\
\hline G. idaeicola & ICMP:11546 & Actinidia deliciosa & New Zealand & KC145891 & $\ldots$ & $\ldots$ & $\ldots$ \\
\hline G. idaeicola & ICMP: 10075 & R. fruticosus & New Zealand & $\mathrm{KC} 145872$ & $\ldots$ & $\ldots$ & $\ldots$ \\
\hline G. idaeicola & KMS4-14 & R. fruticosus & Serbia & MF537338 & MG860499 & MG755816 & MG860489 \\
\hline G. idaeicola & KVR2-14 & R. fruticosus & Serbia & MF537339 & MG860500 & MG773585 & MG860490 \\
\hline G. idaeicola & KRU9-15 & R. fruticosus & Serbia & MF537340 & MG860501 & MG773586 & MG860491 \\
\hline G. idaeicola & KNEI7-15 & R. fruticosus & Serbia & MF537341 & MG860502 & MG773587 & MG860492 \\
\hline G. idaeicola & KZAI1-15 & R. fruticosus & Serbia & MF537342 & MG860503 & MG773588 & MG860493 \\
\hline G. idaeicola & KMI5-15 & R. fruticosus & Serbia & MF537337 & MG860504 & MG773589 & MG860494 \\
\hline G. idaeicola & KDK28-16 & R. fruticosus & Serbia & MF537333 & MG860505 & MG773590 & MG860495 \\
\hline G. idaeicola & KPK10-16 & R. fruticosus & Serbia & MF537334 & MG860506 & MG773591 & MG860496 \\
\hline G. idaeicola & KAR2-16 & R. fruticosus & Serbia & MF537335 & MG860507 & MG773592 & MG860497 \\
\hline G. idaeicola & KKR7-16 & R. fruticosus & Serbia & MF537336 & MG860508 & MG773593 & MG860498 \\
\hline G. idaeicola & KSV1-16 & R. fruticosus & Serbia & MG878401 & MG878402 & MG878403 & MG878404 \\
\hline G. idaeicola & KMS2-14 & R. fruticosus & Serbia & MG893859 & $\ldots$ & $\ldots$ & $\ldots$ \\
\hline G. idaeicola & KMS6-14 & R. fruticosus & Serbia & MG893860 & $\ldots$ & $\ldots$ & $\ldots$ \\
\hline G. idaeicola & KMS12-14 & R. fruticosus & Serbia & MG893861 & $\ldots$ & $\ldots$ & $\ldots$ \\
\hline G. idaeicola & KVR1-14 & R. fruticosus & Serbia & MG893862 & $\ldots$ & $\ldots$ & $\ldots$ \\
\hline G. idaeicola & KMI8-15 & R. fruticosus & Serbia & MG893863 & $\ldots$ & $\ldots$ & $\ldots$ \\
\hline G. idaeicola & KRU7-15 & R. fruticosus & Serbia & MG893864 & $\ldots$ & $\ldots$ & $\ldots$ \\
\hline G. idaeicola & KZAIII3-15 & R. fruticosus & Serbia & MG893865 & $\ldots$ & $\cdots$ & $\cdots$ \\
\hline G. macounii & AR 3866; CBS 121468 & Spiraea sp. & U.S.A. (NY) & EU254762 & EU219126 & GU320804 & JF274641 \\
\hline G. occulta & CBS 125677 & Potentilla sp. & U.S.A. (OR) & GU320828 & $\ldots$ & $\ldots$ & $\ldots$ \\
\hline G. occulta & CBS 125678 & Potentilla sp. & U.S.A. (OR) & GU320829 & GU320786 & GU320800 & $\mathrm{JF} 274650$ \\
\hline G. occulta & BPI 877455 & Potentilla anserina & Russia & EU254811 & $\ldots$ & $\ldots$ & $\ldots$ \\
\hline G. paraclavulata & CBS 123202 & Quercus alba & U.S.A. (MD) & GU320830 & GU320775 & GU320815 & JF274642 \\
\hline G. racemula & CBS 121469; AR 3892 & Epilobium angustifolium & U.S.A. (MN) & EU254841 & $\ldots$ & $\ldots$ & $\ldots$ \\
\hline G. sanguisorbae & CBS 858.79 & Sanguisorba minor & Switzerland & GU320818 & GU320790 & GU320805 & JF274648 \\
\hline G. sanguisorbae & CBS 125299 & $R$. parviflorus & U.S.A. (OR) & GU320819 & $\ldots$ & $\ldots$ & $\ldots$ \\
\hline G. tormentillae & CBS 904.79 & Potentilla erecta & Switzerland & EU254856 & EU219165 & GU320795 & JF274649 \\
\hline Ophiognomonia setacea & CBS 128354 & Quercus sp. & U.S.A. (NJ) & JF514847 & JF514839 & JF514823 & JF274652 \\
\hline Plagiostoma euphorbiae & CBS 340.78 & Euphorbia palustris & Netherlands & EU199198 & $\ldots$ & $\ldots$ & $\ldots$ \\
\hline Plagiostoma sp. & CBS 128351 & Acer sp. & U.S.A. (NY) & JF514852 & JF514836 & JF514833 & $\mathrm{JF} 274651$ \\
\hline Sirococcus conigenus & CBS 113.75 & Picea pungens & Germany & EF512482 & EU219129 & EF512544 & JF274643 \\
\hline S. piceicola & CBS 119620 & Picea sitchensis & Canada & EF512480 & $\ldots$ & $\ldots$ & $\ldots$ \\
\hline S. tsugae & CBS 119627 & Cedrus deodara & U.S.A. (OR) & EF512478 & $\ldots$ & $\ldots$ & $\ldots$ \\
\hline S. tsugae & CBS 128356 & Tsuga canadensis & U.S.A. (ME) & JF514853 & JF514844 & JF514834 & JF274655 \\
\hline Gnomoniopsis sp. & GiM & R. fruticosus & Iran & KJ563296 & $\ldots$ & $\ldots$ & $\ldots$ \\
\hline
\end{tabular}


(Tamura et al. 2013), and deposited in GenBank (Table 2). All generated sequences were compared with each other by calculating nucleotide (nt) identities, as well as with previously deposited Gnomoniopsis spp. isolates available in GenBank, using the similarity search tool BLAST.

Phylogenetic analysis. Newly generated ITS, $\beta$-tubulin, tef- $1 \alpha$, and FG1093 sequences were analyzed with all G. idaeicola sequences available in NCBI and previously listed type-derived sequences of Gnomoniopsis spp. (Walker et al. 2010, 2012). The analyses of individual ITS gene alignment for identification of Serbian isolates and the analyses of concatenated four-gene combined alignment for in-depth characterization were performed using MEGA6 software (Tamura et al. 2013). ITS region alignment consisted of sequences of 18 Serbian and 31 reference isolates of Gnomoniopsis spp., three isolates of Sirococcus spp., and two outgroup taxa: Apiognomonia veneta (Sacc. \& Speg.) Höhn and Plagiostoma euphorbiae (Fuckel) Fuckel from the Gnomoniaceae, retrieved from the GenBank (Table 2). A multilocus phylogenetic analysis based on combined sequences of ITS, $\beta$-tubulin, tef- $1 \alpha$, and FG1093 genes included sequences of 11 Serbian and 11 reference isolates of Gnomoniopsis spp. and two species of Sirococcus, compiled with the outgroup taxa: Plagiostoma sp. and Ophiognomonia setacea (Pers.) Sogonov (Table 2).

Phylogenetic trees were inferred using the maximum likelihood implemented in MEGA version 6.0 software (Tamura et al. 2013) on individual ITS as well as combined data sets for the ITS, $\beta$-tubulin, tef- $1 \alpha$, and FG1093 gene sequences. The gammadistributed Tamura-Nei model determined by Modeltest implemented in MEGA6 was used as the best fitting model of nt

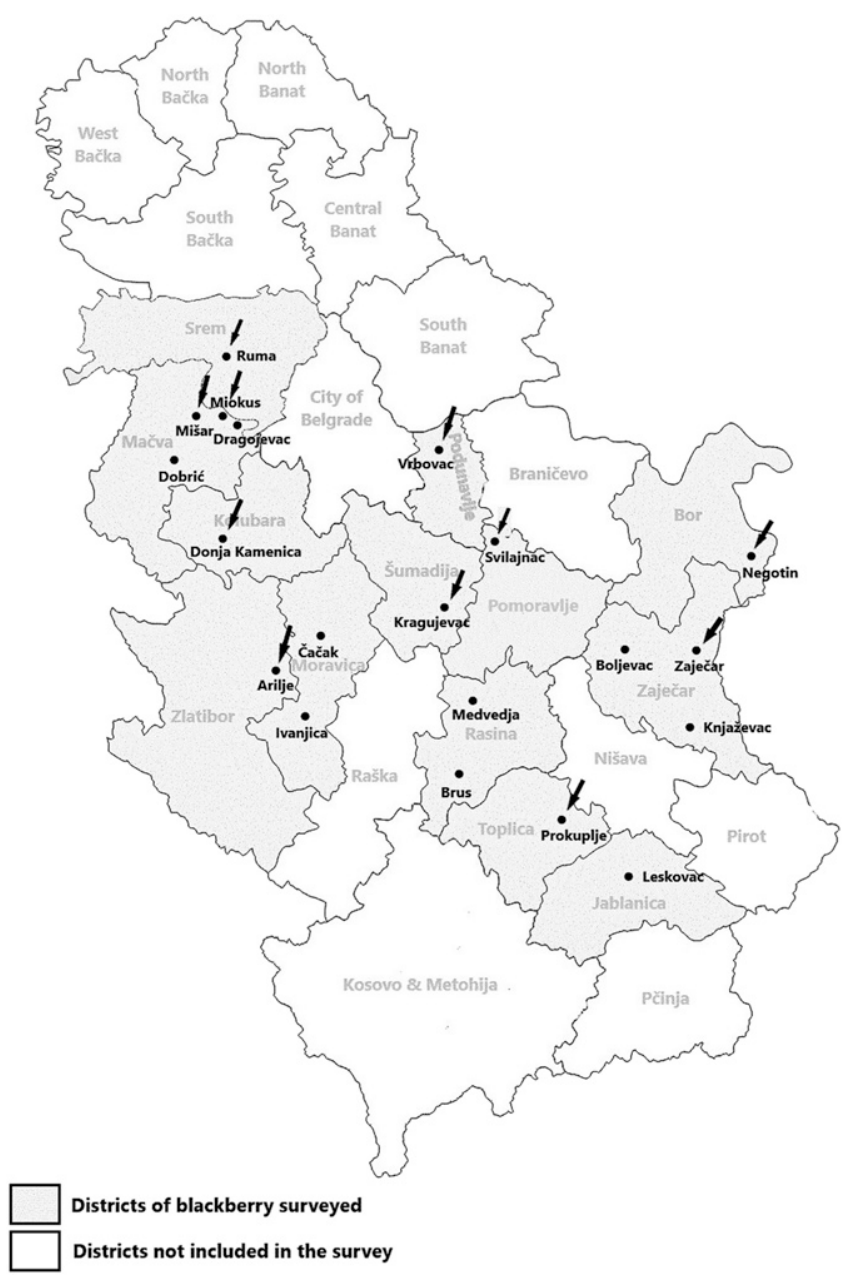

Fig. 1. Geographic distribution of localities in Serbia included in the surveys. Arrows indicate the localities where Gnomoniopsis idaeicola was detected. substitution. The reliability of the obtained trees was evaluated using 1,000 bootstrap replicates, and bootstrap confidence values $<70 \%$ were omitted.

Pathogenicity on blackberry canes. Ten representative isolates of G. idaeicola, sampled in different orchards and years of the survey, were tested for pathogenicity by artificial wound inoculations of primocanes of blackberry cultivar Čačanska bestrna. During September 2017, well-developed primocanes (approximately $15 \mathrm{~mm}$ in diameter) were removed from symptomless blackberry plants in an orchard with no history of cane diseases, transported to the laboratory, and inoculated on the same day. Primocanes were shortened to the length of $40 \mathrm{~cm}$, the foliage and lateral shoots removed, the upper ends sealed with moist cotton wool and Parafilm, and the primocanes placed in $15-\mathrm{cm}$ pots containing sterilized moist sand. For the purpose of inoculation, primocanes were wounded by making clear cuts, approximately $10 \mathrm{~mm}$ long, without damaging the cambial tissue underneath. Mycelial plugs ( $5 \mathrm{~mm}$ in diameter) from the edge of actively growing 15-day-old PDA culture were placed under the bark (mycelial surface face down), and the wound was sealed with sterilized moist cotton wool and Parafilm. As a negative control, primocanes were inoculated with sterile PDA plugs. Each isolate was inoculated into five primocanes, and the experiment was repeated twice. Inoculated primocanes were incubated at $25^{\circ} \mathrm{C}$, cycle of $12 \mathrm{~h}$ light/12 $\mathrm{h}$ darkness, and high humidity. The pathogenicity of isolates was assessed $14 \mathrm{dpi}$ according to the severity of developed symptoms. For the purpose of rating, the following 0 to 5 scale was established: $0=$ no visible symptoms; $1=$ necrosis only on the wounding point; 2 = necrotic tissue exceeding the wounding point up to $2 \mathrm{~cm} ; 3=$ necrotic tissue exceeding the wounding point up to $4 \mathrm{~cm} ; 4=$ necrotic tissue exceeding the wounding point up to $6 \mathrm{~cm}$; and $5=$ visible necrosis longer than $6 \mathrm{~cm}$ around the point of inoculation. All data were analyzed by Kruskal-Wallis test at the $5 \%$ probability level, with individual pairwise comparisons made using Dunn's test. Statistical analyses were performed using XLSTAT software.

\section{Results}

Presence and distribution. During the 4-year survey, the presence of G. idaeicola in Serbia was confirmed at 11 out of 24 localities (Fig. 1, Table 3), in both single (localities of Vrbovac, Miokus, and Svilajnac) and mixed infections. On the basis of their morphology and ITS sequencing (data not presented), different morphospecies, belonging to the genera Paraconiothyrium, Colletotrichum, Diaporthe, Botryosphaeria, Botrytis, Septoria, Neofusicoccum, and Discostroma, were also detected from orchards with and without G. idaeicola presence. The overall isolation rate of $G$. idaeicola was $34.19 \%$ (146 positive out of 427 samples), or $66.06 \%$ (146 positive out of 221 samples) after excluding localities without its presence (Table 3). During 2013, G. idaeicola was not detected, whereas during 2014 to 2016 overall isolation rates were 75.75, 51.85, and $26.75 \%$, respectively (or $75.75,65.88$, and $63.11 \%$, respectively, after excluding localities without its presence). Mostly, only one pathogenic fungus was isolated from each sample. Mixed infections with G. idaeicola and additional pathogenic fungi in the same sample were recorded in 17 out of 221 samples $(7.69 \%)$.

In all surveyed orchards, overall cane disease incidence was 5 to $80 \%$ (average $37.71 \%$ ) (Table 3), whereas in G. idaeicola-positive orchards it was in the range of 10 to $80 \%$ (average $44.09 \%$ ). In the localities of Svilajnac and Miokus, where G. idaeicola was the only detected pathogen, symptoms were present in a very high incidence of 70 and $80 \%$, respectively, with a high intensity of leaf necrosis and cane wilting (Fig. 2A).

In orchards with Serbian cultivar Čačanska bestrna, G. idaeicola was widely distributed (in 8 out of 16 surveyed orchards, disease incidence up to $80 \%$ ). The presence of $G$. idaeicola was also detected in orchards with cultivars Loch Ness (locality of Svilajnac, incidence of 70\%) and Thornfree (localities of Mišar and Donja Kamenica, incidences of 35 and $25 \%$, respectively). Cultivars Chester Thornless and Triple Crown, represented in the survey in only one orchard each, were not infected with $G$. idaeicola. 
Symptomatology and impact. In all surveyed orchards, particularly those infected solely with G. idaeicola, the first visible symptoms on blackberry primocanes were conspicuous, smaller or larger, mostly elliptic necrotic lesions. Lesions were commonly present on nodes and internodes and had brownish-red, dark red, or grayish-black discoloration and a prominent purple border. Over time, lesions enlarged and coalesced, forming large necrotic areas and cankers, usually girdling the canes, and the bark within the diseased area became pale, grayish to silver (Fig. 2B). Larger cankers often split longitudinally, revealing discolored and disorganized necrotic pith. Numerous small black fruiting subepidermal conidiomata, utterly scattered with erumpent ostioles, were frequently recorded on necrotic areas of the canes (Fig. 2K). In the spring, heavily infected overwintered floricanes exhibited reduced lateral growth, with leaves becoming chlorotic followed by necrosis, prominent wilting, and decay. Fruits on such canes either failed to develop or developed to a reduced size, or even ceased to develop prematurely. All of that caused significant yield reduction. Yield losses

Table 3. Geographic distribution of Gnomoniopsis idaeicola isolates collected in Serbia in the survey conducted from 2013 to 2016

\begin{tabular}{|c|c|c|c|c|c|c|c|c|}
\hline \multirow[b]{2}{*}{ Year } & \multirow[b]{2}{*}{ Locality } & \multirow{2}{*}{$\begin{array}{l}\text { Blackberry } \\
\text { cultivar }\end{array}$} & \multirow{2}{*}{$\begin{array}{c}\text { No. of samples/ } \\
\text { G. idaeicola positive } \\
\text { samples }\end{array}$} & \multirow{2}{*}{$\begin{array}{l}\text { Incidence of cane } \\
\text { disease symptoms } \\
\qquad(\%)\end{array}$} & \multirow[b]{2}{*}{ Additional fungi isolated ${ }^{v}$} & \multirow{2}{*}{$\begin{array}{c}\text { No. with } \\
\text { mixed } \\
\text { infection }\end{array}$} & \multicolumn{2}{|c|}{$\begin{array}{l}\text { G. idaeicola } \\
\text { isolates }\end{array}$} \\
\hline & & & & & & & Culture & PCR \\
\hline \multirow[t]{2}{*}{2013} & Leskovac & $\begin{array}{c}\text { Čačanska } \\
\text { bestrna }\end{array}$ & $15 / 0$ & $55^{\mathrm{w}}$ & Paraconiothyrium spp. & $\cdots$ & 0 & 0 \\
\hline & Dragojevac & $\begin{array}{l}\text { Čačanska } \\
\text { bestrna }\end{array}$ & $28 / 0$ & 40 & $\begin{array}{l}\text { Colletotrichum spp. } \\
\text { Paraconiothyrium spp. } \\
\text { Diaporthe spp. } \\
\text { Botryosphaeria spp. }\end{array}$ & $\cdots$ & 0 & 0 \\
\hline \multirow[t]{2}{*}{2014} & Vrbovac & $\begin{array}{l}\text { Čačanska } \\
\text { bestrna }\end{array}$ & $10 / 10$ & 15 & - & $\cdots$ & $3^{x}$ & $2^{y}$ \\
\hline & Mišar & Thornfree & $23 / 15$ & 35 & $\begin{array}{l}\text { Paraconiothyrium spp. } \\
\text { Diaporthe spp. }\end{array}$ & $4^{z}$ & 6 & 4 \\
\hline \multirow[t]{6}{*}{2015} & Miokus & $\begin{array}{l}\text { Chester } \\
\text { Thornless }\end{array}$ & $5 / 0$ & 70 & $\begin{array}{l}\text { Paraconiothyrium spp. } \\
\text { Botryosphaeria spp. }\end{array}$ & $\cdots$ & 0 & 0 \\
\hline & & $\begin{array}{l}\text { Čačanska } \\
\text { bestrna }\end{array}$ & $8 / 8$ & 80 & $\cdots$ & $\cdots$ & 2 & 2 \\
\hline & Dobrić & $\begin{array}{c}\text { Čačanska } \\
\text { bestrna }\end{array}$ & $18 / 0$ & 40 & $\begin{array}{l}\text { Botrytis spp. } \\
\text { Botryosphaeria spp. }\end{array}$ & $\cdots$ & 0 & 0 \\
\hline & Ruma & $\begin{array}{l}\text { Čačanska } \\
\text { bestrna }\end{array}$ & $25 / 16$ & 25 & $\begin{array}{l}\text { Botryosphaeria spp. } \\
\text { Botrytis spp. }\end{array}$ & 6 & 9 & 2 \\
\hline & Negotin & $\begin{array}{l}\text { Čačanska } \\
\text { bestrna }\end{array}$ & $26 / 13$ & 45 & $\begin{array}{l}\text { Septoria spp. } \\
\text { Botryosphaeria spp. } \\
\text { Diaporthe spp. }\end{array}$ & 1 & 10 & 1 \\
\hline & Zaječar & $\begin{array}{l}\text { Čačanska } \\
\text { bestrna }\end{array}$ & $26 / 19$ & 60 & $\begin{array}{l}\text { Paraconiothyrium spp. } \\
\text { Neofusicoccum spp. }\end{array}$ & 4 & 11 & 2 \\
\hline \multirow[t]{14}{*}{2016} & Boljevac & $\begin{array}{l}\text { Čačanska } \\
\text { bestrna }\end{array}$ & $17 / 0$ & 20 & $\begin{array}{l}\text { Botryosphaeria spp. } \\
\text { Paraconiothyrium spp. } \\
\text { Septoria } \text { spp. }\end{array}$ & $\cdots$ & 0 & 0 \\
\hline & Knjaževac & $\begin{array}{l}\text { Čačanska } \\
\text { bestrna }\end{array}$ & $5 / 0$ & 5 & Septoria spp. & $\cdots$ & 0 & 0 \\
\hline & Medveđa & $\begin{array}{l}\text { Čačanska } \\
\text { bestrna }\end{array}$ & $23 / 0$ & 30 & $\begin{array}{l}\text { Septoria spp. } \\
\text { Paraconiothyrium spp. }\end{array}$ & $\cdots$ & 0 & 0 \\
\hline & $\begin{array}{l}\text { Donja } \\
\text { Kamenica }\end{array}$ & Thornfree & $17 / 6$ & 25 & $\begin{array}{l}\text { Paraconiothyrium spp. } \\
\text { Botryosphaeria spp. }\end{array}$ & 2 & 3 & 1 \\
\hline & & $\begin{array}{l}\text { Triple } \\
\text { Crown }\end{array}$ & $5 / 0$ & 5 & Discostroma spp. & $\cdots$ & 0 & 0 \\
\hline & & Loch Ness & $23 / 0$ & 40 & Septoria spp. & $\ldots$ & 0 & 0 \\
\hline & Ivanjica & $\begin{array}{c}\text { Čačanska } \\
\text { bestrna }\end{array}$ & $12 / 0$ & 30 & Septoria spp. & $\cdots$ & 0 & 0 \\
\hline & & Loch Ness & $9 / 0$ & 25 & Septoria spp. & $\ldots$ & 0 & 0 \\
\hline & Arilje & $\begin{array}{l}\text { Čačanska } \\
\text { bestrna }\end{array}$ & $5 / 3$ & 10 & Paraconiothyrium spp. & $\cdots$ & 1 & 1 \\
\hline & Čačak & Loch Ness & $29 / 0$ & 20 & $\begin{array}{l}\text { Septoria spp. } \\
\text { Colletotrichum spp. }\end{array}$ & $\cdots$ & 0 & 0 \\
\hline & Kragujevac & $\begin{array}{l}\text { Čačanska } \\
\text { bestrna }\end{array}$ & $25 / 11$ & 70 & $\begin{array}{l}\text { Paraconiothyrium spp. } \\
\text { Botryosphaeria spp. } \\
\text { Colletotrichum spp. }\end{array}$ & $\cdots$ & 3 & 1 \\
\hline & Prokuplje & $\begin{array}{l}\text { Čačanska } \\
\text { bestrna }\end{array}$ & $26 / 15$ & 50 & $\begin{array}{l}\text { Paraconiothyrium spp. } \\
\text { Septoria spp. }\end{array}$ & $\cdots$ & 7 & 1 \\
\hline & Brus & $\begin{array}{l}\text { Čačanska } \\
\text { bestrna }\end{array}$ & $17 / 0$ & 40 & $\begin{array}{l}\text { Paraconiothyrium spp. } \\
\text { Septoria spp. } \\
\text { Botrytis spp. }\end{array}$ & $\cdots$ & 0 & 0 \\
\hline & Svilajnac & Loch Ness & $30 / 30$ & 70 & $\ldots$ & $\ldots$ & 10 & 1 \\
\hline
\end{tabular}

${ }^{v}$ Isolated pathogenic morphospecies identified to the genera level on the basis of morphology and ITS sequencing.

${ }^{\mathrm{w}}$ Disease incidence estimated by randomly counting and rating 100 plants.

${ }^{x}$ Number of single-spore isolates in the isolate collection.

y Number of isolates characterized by sequencing of ITS or of ITS, $\beta$-tubulin, tef- $1 \alpha$, and FG1093.

${ }^{\mathrm{z}}$ Number of samples in which $G$. idaeicola was present in mixed infections. 
could not be estimated in all localities and investigated years, but at the locality of Svilajnac, in the orchard in the third year of orchard exploitation, where G. idaeicola was the only isolated pathogen, a plant death rate of over $40 \%$ and yield loses estimated at $50 \%$ were recorded in 2016.

Morphological characterization. All 11 single-spore isolates of G. idaeicola, which were morphologically characterized, formed cottony, white, and fast-growing colonies on PDA, with entire or slightly undulate margins and moderate to dense aerial mycelia. After 10 days of incubation, isolates exhibited a different type of growth, forming smooth (KRU9-15, KMS4-14, KDK28-16, and KSV116), curled (KMI5-15, KVR2-14, KZAI1-15, and KKR7-16), or rosaceous (KNEI7-15, KPK10-16, and KAR2-16) colonies (Fig. 2E to $\mathrm{G}$, Table 4), all with no visible conidiomata. Most isolates formed conidiomata at $20 \mathrm{dpi}$, and the colonies became beige to pale brown.

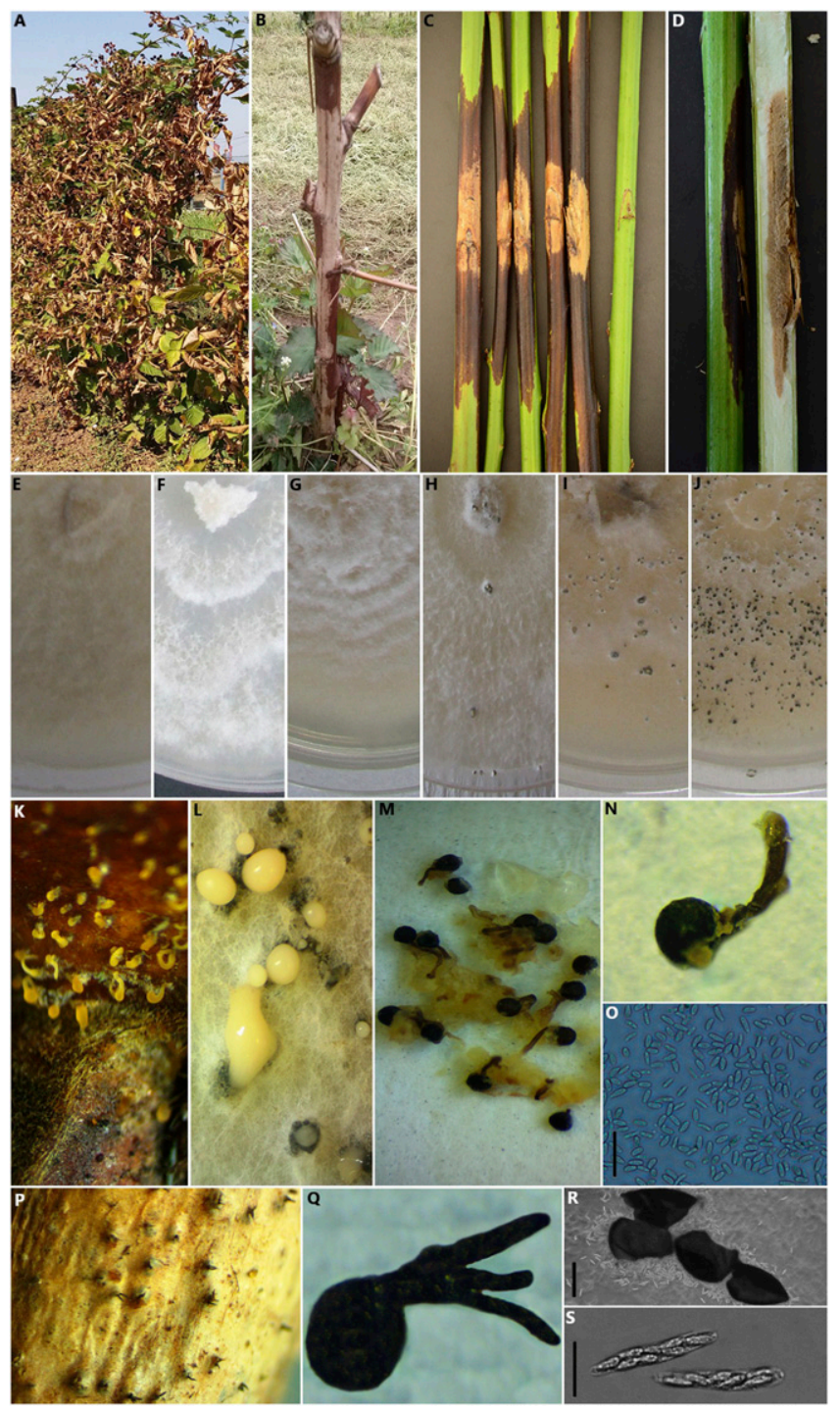

Fig. 2. Symptomatology and morphology of Gnomoniopsis idaeicola isolates from Serbia: A, blackberry leaf necrosis and wilting; B, canker and bark silvering; C, artificially inoculated primocanes (left) and negative control (right); D, bark and pith necrosis of artificially inoculated primocanes; $\mathbf{E}$ to $\mathbf{G}$, smooth, rosaceous, and curled types of colonies on potato dextrose agar (PDA), respectively; $\mathbf{H}$ to $\mathbf{J}$, weak, moderate, and intensive conidiomata formation on PDA, respectively; $\mathbf{K}$, conidiomata immersed in the blackberry bark; $L$, conidial mass releasing on PDA; $\mathbf{M}$, stromatic structure containing pycnidia; $\mathbf{N}$, isolated pycnidium; $\mathbf{0}$, one-celled conidia; $\mathbf{P}$, perithecia immersed in the blackberry bark; $\mathbf{Q}$, isolated perithecium with secondary branched neck; $\mathbf{R}$, crushed perithecia and asci; and $\mathbf{S}$, asci containing ascospores. Scale bars of conidia and asci containing ascospores $=20 \mu \mathrm{m}$. Scale bar of crushed perithecia and asci $=200 \mu \mathrm{m}$.
Conidiomata were present in the colonies of all the isolates $40 \mathrm{dpi}$, but with differences in sporulation intensity. Delayed conidiomata formation (absent in 20-day-old cultures) followed by low sporulation intensity was exhibited by the isolates KMI5-15, KMS4-14, KDK28-16, and KAR2-16. This group of isolates formed only a few individual conidiomata per colony at $40 \mathrm{dpi}$ (Fig. 2H). The isolates KVR2-14, KPK10-16, and KSV1-16 exhibited moderate sporulation intensity (Fig. 2I), whereas the isolates KRU9-15, KNEI7-15, KZAI1-15, and KKR7-16 formed numerous conidiomata, densely distributed all over the colonies (Fig. 2J). The growth rate of all 11 representative isolates on PDA was 2.1 to $3.0 \mathrm{~mm} /$ day (on average $2.66 \mathrm{~mm} /$ day $)$, with no significant differences $(P=0.313)$ (Table 4).

Conidiomata of all 11 isolates (Fig. 2L to O) had uniform features and were immersed in yellowish-brown stromatic structures, each containing 3 to 50 subglobular black pycnidia (125 to $250 \mu \mathrm{m}$ in diameter, $193.82 \mu \mathrm{m}$ on average). Pycnidia had long necks (371 to $480 \mu \mathrm{m}$, on average $421.09 \mu \mathrm{m}$ ), and conidia were hyaline, onecelled, ellipsoid to fusiform, occasionally slightly curved, and 4.5 to $7.25 \times 2.15$ to $3.02 \mu \mathrm{m}$ (average $5.84 \times 2.55 \mu \mathrm{m}$ ) in size. Beige drops of conidial mass, exuding from pycnidia, were visible on the surface of stromatic structures at 20 to $40 \mathrm{dpi}$. There were no significant differences between the isolates in terms of the appearance and dimension of any asexual structure $(P>0.05)$.

None of the isolates formed perithecia on PDA during 5 months of cultivation, and the morphology of sexual structures was studied after field observation. During the survey, the presence of perithecia, protruding through host epidermis, was observed on overwintered canes only in one orchard of cultivar Čačanska bestrna (locality of Miokus) (Fig. 2P to S). The identity of sexual structures was confirmed by ITS sequencing. Perithecia were solitary, numerous, black, and subglobose (195 to $300 \mu \mathrm{m}$ in diameter, on average $275 \mu \mathrm{m}$ ), having a central neck with secondary branching (341 to $461 \mu \mathrm{m}$, on average $421 \mu \mathrm{m})$. Asci were numerous, hyaline, and fusiform (33 to $44.9 \times 6.61$ to $9.56 \mu \mathrm{m}$, on average $40.54 \times 8.24 \mu \mathrm{m}$ ), containing six to eight hyaline, two-celled obovoid ascospores $(6.77$ to $11.4 \times 2.62$ to $3.55 \mu \mathrm{m}$, on average $8.65 \times 3.08 \mu \mathrm{m})$.

Molecular identification and sequence analysis. BLAST analyses of all the four targeted genome regions (ITS, $\beta$-tubulin, tef- $1 \alpha$, and FG1093) supported conventional identification of selected Serbian G. idaeicola isolates. All 18 Serbian ITS sequences shared the similarity of 99.3 to $100 \%$ (4 bp differences), and BLAST analysis revealed the highest nt identities of 99 to $100 \%$ (100\% query coverage) with two sequences of $G$. idaeicola from New Zealand (KC145872 and KC145891), two from France (KT692597 and NR145281), and one from Spain (KC959208). The $\beta$-tubulin sequences of the 11 Serbian G. idaeicola isolates shared similarity of 98.9 to $100 \%$ (8 bp differences), and BLAST results revealed nt identity of 98 to $100 \%$ with G. idaeicola isolates from the United States and France (GU320781, GU320780, GU320783, and GU320784). The tef- $1 \alpha$ sequences of Serbian isolates showed nt identities of 99.4 to $100 \%$ ( 7 bp differences), and BLAST analysis confirmed the highest nt homology of $99 \%$ with four G. idaeicola isolates from the United States (GU320796 to GU320799) and one from France (GU320796). The FG1093 sequences of all the 11 Serbian G. idaeicola isolates proved to be $100 \%$ identical at the nt level, as well as with the only available G. idaeicola isolate from Rubus armeniacus from the United States (JF274654).

Molecular characterization and phylogeny. Maximum likelihood analyses of the ITS sequence alignment of 54 sequences of $534 \mathrm{nt}$ each, including the outgroup taxa, resulted in a phylogenetic tree with established resolution and topology for Gnomoniopsis spp. (Fig. 3). All G. idaeicola isolates grouped together in one main clade with high bootstrap support (98\%), containing all Serbian blackberry isolates as well as nine $G$. idaeicola isolates from different hosts and of different geographic origin (United States, Spain, France, and New Zealand). Blackberry isolate Gnomoniopsis sp. from Iran (GiM) was also included in G. idaeicola clade but on a separate branch $(99 \%$ bootstrap support).

Multilocus analysis, based on the Tamura-Nei model assuming gamma distribution (Tamura et al. 2013), resulted in a maximum 
likelihood tree for the four concatenated loci. The ITS, $\beta$-tubulin, tef$1 \alpha$, and FG1093 sequence alignments consisted of 530, 788, 1,123, and $426 \mathrm{nt}$, respectively (2,867 nt in total), of 26 different isolates, including the outgroup taxa. At the Gnomoniopsis genus level, the phylogenetic tree with the combined data set (Fig. 4) shared similar topology with the ITS single locus tree obtained in this study. Better resolution was obtained within the species-specific G. idaeicola clade, which contained almost exclusively Serbian isolates (except for the isolate CBS 125676 from the United States). Within the clade, G. idaeicola isolates were, with great confidence, separated into two subgroups (bootstrap support of $100 \%$ ). The first branch included the single Serbian isolate KSV1-16, whereas the remaining 10 Serbian isolates and one isolate from the United States grouped in the second branch, showing an additional subgrouping of still unclear significance.

Pathogenicity. All 10 reference G. idaeicola isolates caused development of prominent symptoms on inoculated blackberry primocanes at $14 \mathrm{dpi}$, confirming their pathogenicity and satisfying Koch's postulates. The symptoms were visible as dark brown to gray bark discoloration, with numerous black conidiomata around the point of inoculation (Fig. 2C). The intensity of developed symptoms and sporulation were different with each G. idaeicola isolate (Table 4). Silvering of bark near the inoculation point was noticeable after inoculation with almost all the isolates, resembling the symptoms of natural infection. Regardless of the intensity of bark necrosis, all the isolates colonized internal tissue, causing brown discoloration and partial pith disintegration (Fig. 2D). In all symptomatic primocanes, the presence of $G$. idaeicola was confirmed by reisolation and morphological comparison with a respective isolate. There were no visible symptoms and no pathogen isolated from negative control primocanes inoculated with sterile PDA plugs.

Differences in virulence among the Serbian G. idaeicola isolates were determined by comparing the symptom intensity (Table 4). Three isolates, with the highest and the lowest virulence, were significantly different $(P<0.01)$ in terms of the size of necrotic area, the size of bark silvering area, and the number of conidiomata. The most virulent was the isolate KMI5-15 (median rate 5), which caused formation of large dark gray lesions (up to $12 \mathrm{~cm}$ long), bark silvering over $3 \mathrm{~cm}$ long, and numerous pycnidia. As the opposite, the lowest virulence was exhibited by the isolates KDK28-16 and KKR7-16 (median rates 3 and 2, respectively), which caused necrosis only on wounded bark and formed only a small number of pycnidia (and for isolate KKR7-16 not in all repetitions). The remaining seven isolates also showed a trend of slightly different virulence, but with no significant distinctions $(P>0.05)$.

\section{Discussion}

In this paper we described the first results of a 4-year survey on the presence and distribution of G. idaeicola, a new pathogen of blackberry in Serbia. To the best of our knowledge, this is the first record of a massive outbreak of G. idaeicola in a blackberry production area in Europe, as well as in the world. Generally, G. idaeicola was found to be distributed in almost half of the surveyed orchards, in three blackberry cultivars, with medium to high disease incidence (up to $80 \%$ ). Such distribution and incidence suggest that the presence of G. idaeicola in Serbia is not the result of a recent introduction and that the pathogen has already been established on the territory of Serbia. There are at least two main reasons why the pathogen's presence could have remained undetected. First, no diagnostically specific symptoms caused by $G$. idaeicola were observed on the blackberry leaves and canes. It can be assumed that the symptoms of G. idaeicola infection were noticed but were attributed to other causal agents. Cankers caused by $G$. idaeicola observed during this study greatly resembled the previous descriptions of Leptosphaeria and Botryosphaeria infections on blackberry in Serbia and worldwide (Arsenijević 2006b; Martin et al. 2017) and could not be distinguished solely on the basis of symptomatology. On the other hand, blackberry production in Serbia has expanded quickly recently and, during the period 1997 to 2005, blackberry growing areas and yields tripled. At the same time, the composition of cultivars has been changed, and domestic cultivar Čačanska bestrna became prevalent, occupying approximately $60 \%$ of the growing area (Nikolić and Milivojević 2015). During that dynamic period, a number of orchards were established with planting material of uncontrolled and uncertain health status.

Although there are no data on economic significance and impact of G. idaeicola in comparison with other pathogens (Martin et al. 2017),

Table 4. Morphological and pathogenic characterization of Gnomoniopsis idaeicola isolates from blackberry in Serbia after inoculation of primocanes of blackberry cultivar Čǎanska bestrna

\begin{tabular}{|c|c|c|c|c|c|c|c|c|}
\hline Isolate & $\begin{array}{c}\text { Year of } \\
\text { isolation }\end{array}$ & Locality & Cultivar & $\begin{array}{l}\text { Mean growth } \\
\text { rate }\end{array}$ & $\begin{array}{c}\text { Colony } \\
\text { appearance }\end{array}$ & $\begin{array}{c}\text { Sporulation in } \\
\text { vitrow }^{w}\end{array}$ & $\begin{array}{l}\text { Median virulence } \\
\text { rate }\end{array}$ & $\begin{array}{l}\text { Sporulation } \\
\text { in vivo }\end{array}$ \\
\hline KMI5-15 & 2015 & Miokus & $\begin{array}{c}\text { Čačanska } \\
\text { bestrna }\end{array}$ & $2.8 \mathrm{a}^{\mathrm{y}}$ & Curled & Weak & $5^{\mathrm{z}} \mathrm{a}^{\mathrm{y}}$ & Intensive \\
\hline KRU9-15 & 2015 & Ruma & $\begin{array}{c}\text { Čačanska } \\
\text { bestrna }\end{array}$ & $2.1 \mathrm{a}$ & Smooth & Intensive & $4 a b$ & Intensive \\
\hline KZAI1-15 & 2015 & Zaječar & $\begin{array}{c}\text { Čačanska } \\
\text { bestrna }\end{array}$ & $2.8 \mathrm{a}$ & Curled & Intensive & $4 a b$ & Intensive \\
\hline KPK10-16 & 2016 & Prokuplje & $\begin{array}{c}\text { Čačanska } \\
\text { bestrna }\end{array}$ & $2.5 \mathrm{a}$ & Rosaceous & Moderate & $4 a b$ & Moderate \\
\hline KNEI7-15 & 2015 & Negotin & $\begin{array}{c}\text { Čačanska } \\
\text { bestrna }\end{array}$ & $2.6 \mathrm{a}$ & Rosaceous & Intensive & $3 a b$ & Moderate \\
\hline KAR2-16 & 2016 & Arilje & $\begin{array}{c}\text { Čačanska } \\
\text { bestrna }\end{array}$ & $2.8 \mathrm{a}$ & Rosaceous & Weak & $3 a b$ & Moderate \\
\hline KMS4-14 & 2014 & Mišar & Thornfree & $2.7 \mathrm{a}$ & Smooth & Weak & $3 a b$ & Weak \\
\hline KVR2-14 & 2014 & Vrbovac & $\begin{array}{c}\text { Čačanska } \\
\text { bestrna }\end{array}$ & $2.6 \mathrm{a}$ & Curled & Moderate & $3 a b$ & Weak \\
\hline KDK28-16 & 2016 & $\begin{array}{l}\text { Donja } \\
\text { Kamenica }\end{array}$ & Thornfree & $3.0 \mathrm{a}$ & Smooth & Weak & $3 \mathrm{~b}$ & Weak \\
\hline KKR7-16 & 2016 & Kragujevac & $\begin{array}{c}\text { Čačanska } \\
\text { bestrna }\end{array}$ & $2.6 \mathrm{a}$ & Curled & Intensive & $2 \mathrm{~b}$ & Weak \\
\hline KSV1-16 & 2016 & Svilajnac & Loch Ness & $2.8 \mathrm{a}$ & Smooth & Moderate & $\ldots$ & $\ldots$ \\
\hline
\end{tabular}

${ }^{\mathrm{w}}$ Sporulation intensity estimated from the number of conidiomata formed on potato dextrose agar 40 days postinoculation: intensive $=$ numerous conidiomata distributed all over the colony surface; moderate $=\leq 100$ conidiomata per colony; and weak $=$ a few individual conidiomata per colony.

x Sporulation intensity estimated from the number of conidiomata formed on artificially inoculated blackberry canes 14 days postinoculation: intensive $=$ numerous conidiomata distributed all over necrotic lesions; moderate = medium number of conidiomata formed near the inoculation point; and weak = conidiomata not present or only a few conidiomata formed within the lesions.

y Values followed by a common letter are not significantly different $(P>0.05)$.

$\mathrm{z}$ Median rates are sorted in decreasing order. 
our results showed its capacity to have substantial influence on blackberry production in Serbia and elsewhere. The only previously published estimation of blackberry yield loses that could be related to G. idaeicola originates from Iran (Mirhosseini et al. 2015), although the authors referred to the causal agent as Gnomoniopsis sp. In Iran, blackberry leaf necrosis and blighting reached an incidence of $80 \%$, with $30 \%$ dead plants and yield loses estimated at 50 to $80 \%$. A similar situation was recorded in Serbia, with detected disease incidence caused by $G$. idaeicola of up to $80 \%$. Several producers claimed that they were experiencing substantial loses. The most extreme situation was recorded in a young blackberry orchard of the cultivar Loch Ness (locality of Svilajnac), where the plant death rate reached $40 \%$ and yield loses were estimated at $50 \%$. Considering the importance of blackberry production in Serbia, G. idaeicola has clearly demonstrated the potential to act as a harmful pathogen.

During this study, G. idaeicola was detected on three out of five blackberry cultivars grown in Serbia: domestic cultivar Čačanska bestrna and two international cultivars, Loch Ness and Thornfree. Available data on the host range and on cultivar reactions to infections with Gnomoniopsis spp. and G. idaeicola in particular were limited and with no details (Sogonov et al. 2008; Walker et al. 2010). This study provides the first data on differences between G. idaeicola infections in various blackberry cultivars. Nevertheless, because blackberry cultivars are not equally represented in the production in Serbia and they were consequently represented with different number of samples in our survey, only some of the aspects could be discussed. Additionally, there have been no reports in the

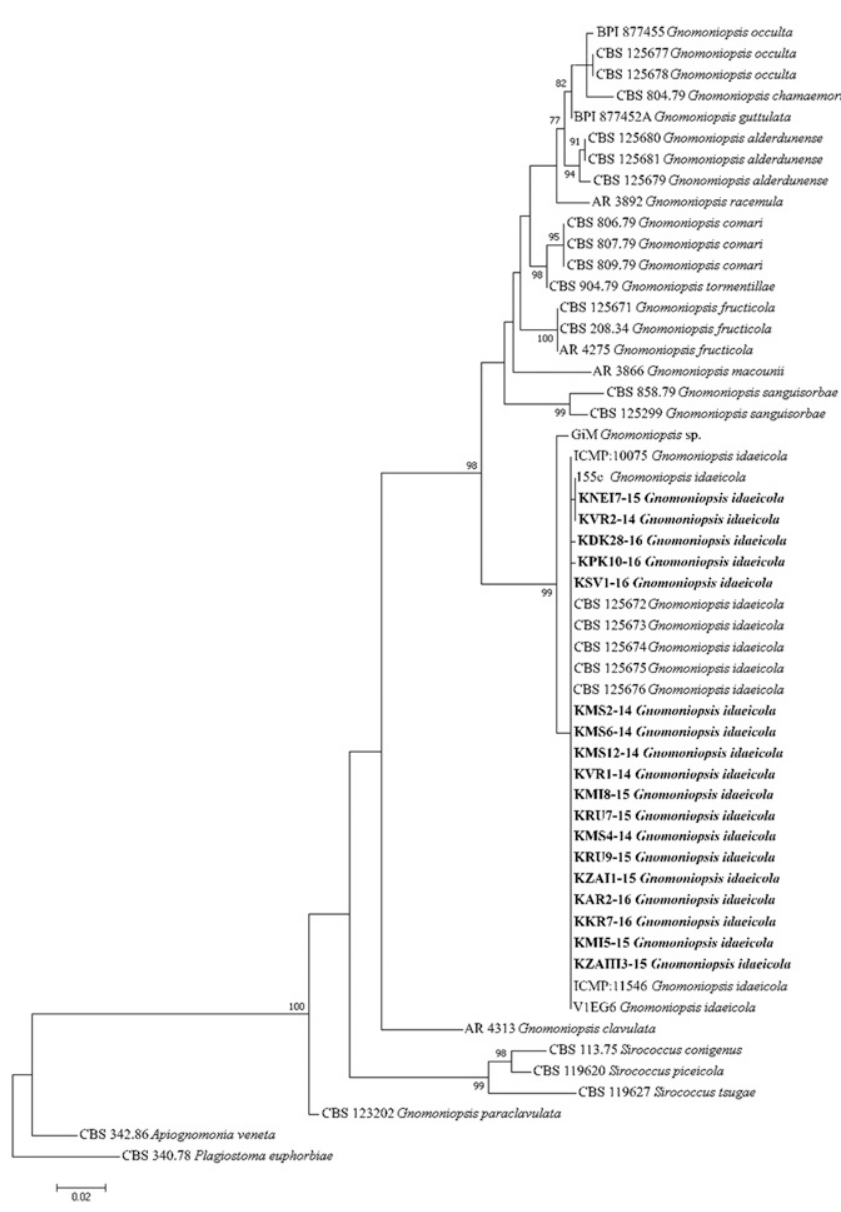

Fig. 3. Maximum likelihood phylogenetic tree of internal transcribed spacer rDNA sequences of 18 Serbian and 31 reference isolates of Gnomoniopsis spp., three isolates of Sirococcus spp., and two outgroup taxa (Apiognomonia veneta and Plagiostoma euphorbiae). The phylogram was generated with MEGA6 using the gamma-distributed Tamura-Nei model (Tamura et al. 2013). Bootstrap analysis was performed with 1,000 replicates, and bootstrap values $(>70 \%)$ are shown next to relevant branches. The Serbian Gnomoniopsis idaeicola isolates are bolded. literature on the correlation between $G$. idaeicola disease incidence and the age of an orchard. Based on field observation, it seems that neither the cultivar type nor the duration of commercial exploitation of an orchard has crucial influence on the level of G. idaeicola infection frequency in Serbia. In orchards with both domestic (Čačanska bestrna) and international cultivars (Loch Ness), the incidence of G. idaeicola infection was high. Similarly, in both young (locality of Svilajnac) and older orchards (locality of Miokus) diseases caused by $G$. idaeicola were also present at a high incidence. Contrary to that, a certain number of inspected blackberry orchards were with no or with little presence of G. idaeicola, regardless of the cultivar type and duration of orchard exploitation. It can be assumed that introduction of G. idaeicola into new production areas was carried out via infected blackberry planting material, whereas short-distance dissemination from plant to plant occurred via water-dispersing conidia. For the comprehensive understanding of complicated aspects of the pathogen epidemiology, such as plant age and cultivar predisposition, as well as dissemination strategies, an additional insight into G. idaeicola biology and reports from other blackberry production areas worldwide would be necessary.

Morphological features of the majority of $G$. idaeicola isolates from this study are in agreement with previous descriptions (Mirhosseini et al. 2015; Walker et al. 2010). However, morphological characterization of Serbian G. idaeicola isolates, originating from different localities, revealed that colony appearance and sporulation capacity varied substantially among the isolates. G. idaeicola colony color was described as a variable feature among isolates of the same or different origin (Mirhosseini et al. 2015; Walker et al. 2010). All isolates examined in this study formed white to beige colonies, which appeared to be a stable characteristic of Serbian G. idaeicola isolates. On the other hand, Serbian isolates demonstrated different growth patterns, particularly in early stages of colony development, forming either smooth, rosaceous, or curled colonies. Isolates from Serbia also varied substantially in regard to in vitro sporulation capacity. Variability in growth pattern had not been reported previously, as well as variability in sporulation intensity. The only available description of Gnomoniopsis spp. (Sogonov et al. 2008) and, particularly, G. idaeicola sporulation capacity (Mirhosseini et al. 2015; Walker et al. 2010) was that several characterized isolates from France, the United States, and Iran exhibited abundant sporulation.

Sexual reproduction was not found to be a common feature among G. idaeicola isolates in Serbia. None of the isolates, originating from different blackberry orchards, produced perithecia in vitro on PDA, although it was expected and previously described (Walker et al. 2010). The presence of perithecia was recorded only in one out of 11 orchards with G. idaeicola blackberry infection. The morphology and dimensions of perithecia, asci, and ascospores were similar to previous descriptions of G. idaeicola (Walker et al. 2010), which supported the conventional identification based on the appearance of asexual structure. Data on G. idaeicola epidemiology, especially on the ways of overwintering and the significance of different sources of inoculum in the world, are limited (Walker et al. 2010). Nevertheless, based on field observation, it seems that perithecia have limited importance in overwintering and as the source of inoculum, at least in Serbia. A completely different dissemination strategy was described for a pathogenic species from the same genera, G. smithogilvyi, on chestnut, in which ascospores dominated as the source of inoculum, whereas conidia had limited or no impact at all (Shuttleworth and Guest 2017). Taking into account that G. idaeicola is widely distributed on blackberry in Serbia, further epidemiological studies would be necessary, especially on the sources of inoculum and the role of wind in disseminating ascospores. This is emphasized by recent records of $G$. idaeicola as a pathogen on host plants other than Rubus spp. in New Zealand (A. Bulajić, personal communication) and as an endophyte in different plants, such as wheat and $M$. communis (Comby et al. 2016; Vaz 2012).

Molecular identification and phylogeny supported the conventional identification of Serbian G. idaeicola isolates. Applying the proposed concept of backbone phylogenetic trees (Hyde et al. 2014), we used a phylogenetic tree with defined and sufficient 
resolution within the genus Gnomoniopsis (Walker et al. 2010). The position of Serbian isolates and all the others from different hosts and parts of the world (Spain, France, and New Zealand) within the $G$. idaeicola branch additionally supported the taxonomy of this welldefined and separated species-specific branch. The G. idaeicola clade also included a Gnomoniopsis sp. isolate from Iran on a slightly distant and well-supported position (Mirhosseini et al. 2015). Two additional Rubus spp. pathogens from the genus Gnomoniopsis, $G$. alderdunense and G. chamaemori (Walker et al. 2010), exhibited clearly distant topology from all G. idaeicola isolates included in the ITS-based phylogenetic tree, additionally confirming the identification of Serbian isolates. According to our results, the ITS rDNA sequence is a confident delineation tool for species-specific G. idaeicola identification.

In multilocus phylogenetic analyses, aiming at further characterization of the Serbian G. idaeicola population, together with the proposed tree loci ITS, $\beta$-tubulin, and tef- $1 \alpha$ (Walker et al. 2010), we included the additional molecular marker FG1093, which codes for the 60 S ribosomal protein L37. FG1093 was described as an attractive genetic marker for species-level phylogenetic studies within the Gnomoniopsis genus (Walker et al. 2012). In our study, the FG1093 gene proved to be highly conserved at a species level for G. idaeicola, but a multilocus phylogenetic tree based on combined data of all four genetic markers provided additional information and represented the first insight into possible intraspecies variability, based on subgrouping within a well-supported branch of G. idaeicola. One Serbian isolate (KSV1-16) positioned separately from all the other Serbian isolates, as well as from the only available G. idaeicola isolate from the United States, which indicated the possibility of its different origin. Considering the frequent import of blackberry planting material into Serbia, it can be expected that some of the Serbian isolates may be of different geographic origin and related to the isolates from different blackberry production areas. Much more data and more characterized isolates are needed for a comprehensive understanding of the biological meaning and phylogenetic relationships among the isolates of G. idaeicola.

Generally, G. idaeicola isolates characterized in this study exhibited strong virulence and caused prominent external and internal cane necrosis after a short incubation period. Moreover, the majority of the isolates formed $>50$ conidiomata on inoculated primocanes only $14 \mathrm{dpi}$, demonstrating the potential for at least several secondary infections and the fast-spreading nature. Interestingly, some of the isolates exhibited an unusual discrepancy in sporulation intensity on host tissue and in culture. The largest number of pycnidia on inoculated primocanes was noticeable after inoculation with the most virulent isolate, KMI5-15, whereas at the same time it exhibited delayed and scarce sporulation on PDA. The least virulent isolate, KKR7-16, exhibited the opposite behavior, with scarce or no sporulation on inoculated primocanes and abundant sporulation on PDA. This suggested that sporulation of some G. idaeicola isolates is mediated by multiple factors and more data are necessary to fully understand the process. Differences in virulence among the species from Gnomoniopsis spp. have rarely been reported. Only Shuttleworth and Guest (2017) reported that isolates of G. smithogilvyi originating from Australia and New Zealand exhibited different virulence after artificial inoculations, compared with the isolates originating from Italy. Because the selected Serbian G. idaeicola isolates also demonstrated different virulence, from mild to severe, their comparison with isolates originating from different parts of the world could give an answer to the question of whether virulence of a certain isolate can be related to its geographic origin.

The results of this study contribute to the research of etiology of blackberry cane diseases and highlight the significance of G. idaeicola, not only as a new pathogen in Serbia but also as a pathogen capable of causing devastating blackberry diseases worldwide. Its wide distribution in different areas and cultivars in Serbia, as well as occasional high disease incidences, indicate that $G$. idaeicola has not been introduced recently and that it has been well established. At the same time, intraspecies variability in morphological, biological, pathogenic, and molecular features implies that the G. idaeicola population in Serbia may be of different origin, and probably the result of more than one introduction. This study represents the first initial step in the study of G. idaeicola, as a new blackberry pathogen in Serbia, and many aspects of its biology and, above all, epidemiology are still unknown. Taking into account its demonstrated capability to cause substantial yield loses and to limit blackberry production, there is a

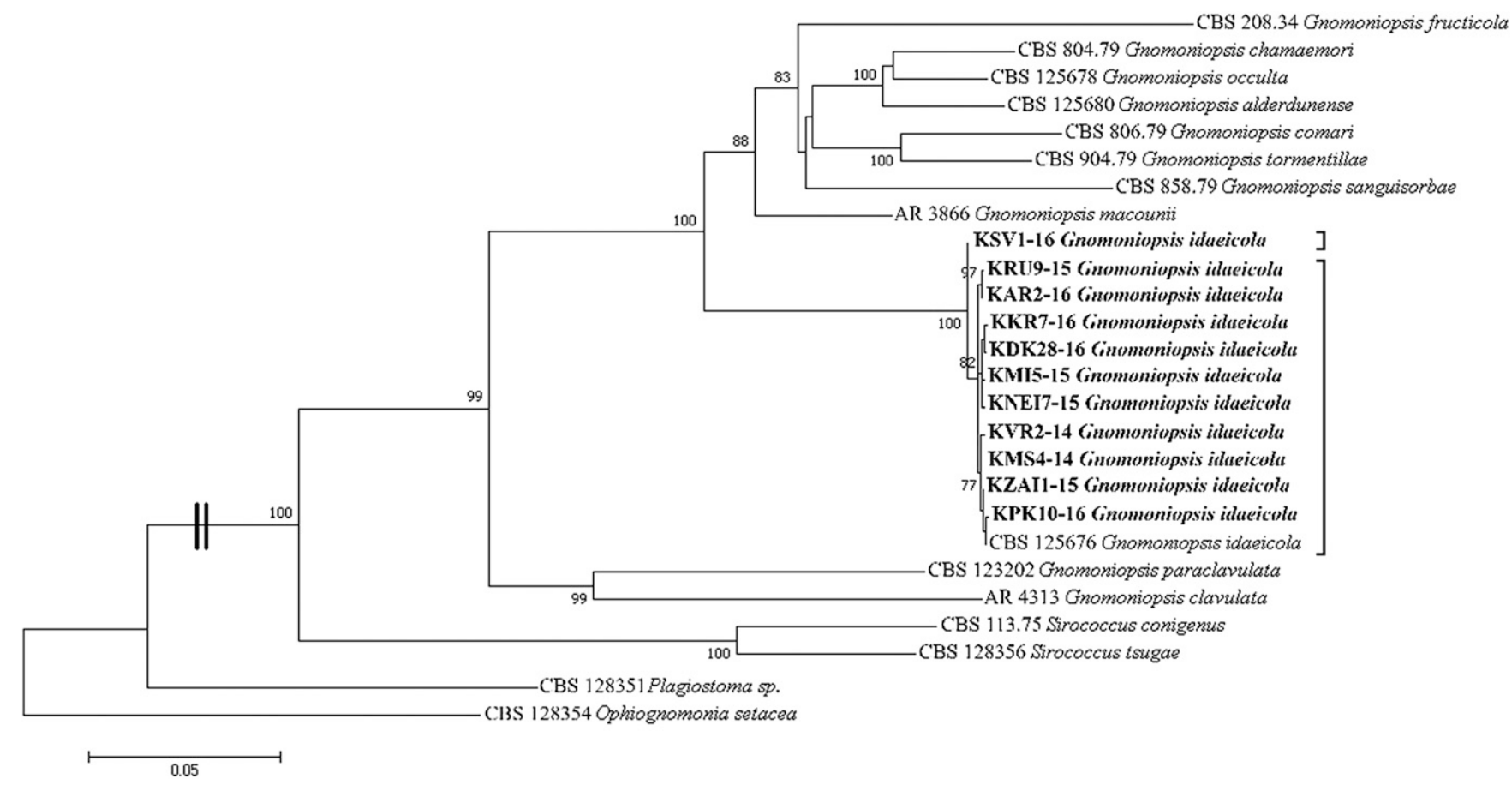

Fig. 4. Maximum likelihood phylogenetic tree inferred from concatenated internal transcribed spacer rDNA, $\beta$-tubulin, tef- $1 \alpha$, and FG1093 sequences of 11 Serbian and 11 reference isolates of Gnomoniopsis spp., two species in Sirococcus, and two outgroup taxa (Plagiostoma sp. and Ophiognomonia setacea). The phylogram was generated with MEGA 6 using the gamma-distributed Tamura-Nei model (Tamura et al. 2013). Bootstrap analysis was performed with 1,000 replicates, and bootstrap values (>70\%) are shown next to relevant branches. The Serbian Gnomoniopsis idaeicola isolates are bolded. 
strong need to include G. idaeicola into a phytosanitary scheme in the production of pathogen-free planting material, as the first step in developing efficient control measures.

\section{Acknowledgments}

The authors are grateful for valuable information and support from blackberry producers in Serbia.

\section{Literature Cited}

Arsenijević, M. 2005. Karakteristike sojeva Phomopsis sp. izolovanih iz izdanaka obolele maline. Acta Agric. Slov. 85:107-115.

Arsenijević, M. 2006a. Vrste gljiva - Prouzrokovači nekroze izdanaka gajene i divlje kupine (I) Septocyta ruborum (Lieb.) Petrak, Gnomonia rostellata (Fr.) Wehm., Phomopsis spp., Didymella applanata (Niessl.) Sacc. Biljni Lek. 1:40-46.

Arsenijević, M. 2006b. Vrste gljiva - Prouzrokovači nekroze izdanaka gajene i divlje kupine (II) Seimatosporium lichenicola, Bothryosphaeria dothidea, Bothryosphaeria obtusa, Coniothyrium fuckelii, Sphaceloma necator, Botrytis cinerea. Biljni Lek. 2:117-124.

Arsenijević, M., Borić, B., Draganić, M., Spica, G., and Aleksić, G. 1999. Cultural characteristics and pathogenicity of Seimatosporium lichenicola (Corda) Shoemaker et Müller isolated from blackberry (Rubus fructicosus L.) plants in Yugoslavia. J. Plant Dis. Prot. 106:353-362.

Arsenijević, M., and Veselić, M. 1995. Gnomonia rostellata (Fr.) Wehm., the pathogen of cultivated blackberry plants (Rubus fructicosus L., agg.). J. Plant Dis. Prot. 102:366-374.

Carbone, I., and Kohn, L. M. 1999. A method for designing primer sets for speciation studies in filamentous ascomycetes. Mycologia 91:553-556.

Castlebury, L. A., Rossman, A. Y., Jaklitsch, W. J., and Vasilyeva, L. N. 2002. A preliminary overview of the Diaporthales based on large subunit nuclear ribosomal DNA sequences. Mycologia 94:1017-1031.

Clark, J. R., and Finn, C. E. 2011. Blackberry breeding and genetics.Fruit Veg. Cereal Sci. Biotechnol. 5:27-43.

Comby, M., Lacoste, S., Baillieul, F., Profizi, C., and Dupont, J. 2016. Spatial and temporal variation of cultivable communities of co-occurring endophytes and pathogens in wheat. Front. Microbiol. 7:403.

Cunnington, J., Aldaoud, R., de Alwis, S., Salib, S., and Doughty, S. 2011. New and interesting records of plant pathogenic fungi from south-eastern Australia. A Handbook of Joint 4th Asian Conference on Plant Pathology and the 18th Biennial Australasian Plant Pathology Society Conference. New Frontiers in Plant Pathology for Asia and Oceania.

Danti, R., Sieber, T. N., and Sanguineti, G. 2002. Endophytic mycobiota in bark of European beech (Fagus sylvatica) in the Apennines. Mycol. Res. 106:1343-1348.

Gardes, M., and Bruns, T. D. 1993. ITS primers with enhanced specificity for basidiomycetes-Application to the identification of mycorrhizae and rusts. Mol. Ecol. 2:113-118

Hyde, K. D., Nilsson, R. H., Alias, S. A., Ariyawansa, H. A., Blair, J. E., Cai, L., de Cock, A. W. A. M., Dissanayake, A. J., Glockling, S. L., Goonasekara, I. D., Gorczak, M., Hahn, M., Jayawardena, R. S., van Kan, J. A. L., Laurence, M. H., André Lévesque, C., Li, X., Liu, J. K., Maharachchikumbura, S. S. N., Manamgoda, D. S., Martin, F. N., McKenzie, E. H. C., McTaggart, A. R., Mortimer, P. E., Nair, P. V. R., Pawlowska, J., Rintoul, T. L., Shivas, R. G., Spies, C. F. J., Summerell, B. A., Taylor, P. W. J., Terhem, R. B., Udayanga, D., Vaghefi, N., Walther, G., Wilk, M., Wrzosek, M., Xu, J. C., Yan, J., and Zhou, N. 2014. One stop shop: Backbones trees for important phytopathogenic genera: I (2014). Fungal Divers. 67:21-125.

Martin, R. R., Ellis, M. A., Williamson, B., and Williams, R. N. 2017. Pages 1-175 in: Compendium of Raspberry and Blackberry Diseases and Pests, 2nd Ed. APS Press, St Paul, MN.
Mirhosseini, H. A., Rahimian, H., Babaeizad, V., and Hashemi, L. 2015. Outbreak of leafspot on blackberry (Rubus fruticosus) caused by Gnomoniopsis sp. in Iran. New Dis. Rep. 31:9.

Nikolić, M., and Milivojević, J. 2015. Jagodaste voćke-Tehnologija gajenja. Poljoprivredni fakultet, Beograd, Serbia.

O’Donnell, K., and Cigelnik, E. 1997. Two divergent intragenomic rDNA ITS2 types within a monophyletic lineage of the fungus Fusarium are nonorthologous. Mol. Phylogenet. Evol. 7:103-116.

Pellegrini, N., Searfini, M., Colombi, B., Del Rio, D., Salvatore, S., Bianchi, M., and Brighenti, F. 2003. Total antioxidant capacity of plant, foods, beverages and oils consumed in Italy assessed by three different in vitro assays. J. Nutr. 133:2812-2819.

Rehner, S. A., and Buckley, E. 2005. A Beauveria phylogeny inferred from nuclear ITS and EF1-a sequences: Evidence for cryptic diversification and links to Cordyceps teleomorphs. Mycologia 97:84-98.

Reyes-Carmona, J., Yousef, G. G., Martinez-Peniche, R. A., and Lila, M. A. 2005. Antioxidant capacity of fruit extracts of blackberry (Rubus sp.) produced in different climatic regions. J. Food Sci. 70:s497-s503.

Rossman, A. T., Farr, D. F., and Castlebury, L. A. 2007. A review of the phylogeny and biology of the Diaporthales. Mycoscience 48:135-144.

Saleemi, M. K., Khan, M. Z., Khan, A., Javed, I., U1 Hasan, Z., Hameed, M. R., Hameed, S., and Mehmood, M. A. 2012. Occurrence of toxigenic fungi in maize and maize-gluten meal from Pakistan. Phytopathol. Mediterr. 51 219-224.

Shuttleworth, L. A., and Guest, D. I. 2017. The infection process of chestnut rot, an important disease caused by Gnomoniopsis smithogilvyi (Gnomoniaceae, Diaporthales) in Oceania and Europe. Australas. Plant Pathol. 46:397-405.

Sogonov, M. V., Castlebury, L. A., Rossman, A. Y., Mejia, L. C., and White, J. F 2008. Leaf-inhabiting genera of the Gnomoniaceae, Diaporthales. Stud. Mycol. 62:1-77.

Sokal, R. R., and Rohlf, F. J. 1995. Biometry: The Principles and Practice of Statistics in Biological Research, 3rd Ed. W. H. Freeman and Company, New York.

Strik, B. C., Clark, J. R., Finn, C. E., and Banados, M. P. 2007. Worldwide blackberry production. HortTechnology 17:205-213.

Tamura, K., Stecher, G., Peterson, D., Filipski, A., and Kumar, S. 2013. MEGA6 Molecular Evolutionary Genetics Analysis Version 6.0. Mol. Biol. Evol. 30: 2725-2729.

Thompson, J. D., Higgins, D. G., and Gibson, T. J. 1994. CLUSTAL W: Improving the sensitivity of progressive multiple sequence alignment through sequence weighting, position-specific gap penalties and weight matrix choice. Nucleic Acids Res. 22:4673-4680

Vaz, A. B. M. 2012. Diversidade e aplicações biotecnológicas de fungos endofíticos associados à espécies da sub-família Mirtoideae (Myrtaceae) presentes em ecossistemas do Brasil, Argentina e Espanha. Ph.D. thesis Universidade Federal de Minas Gerais, Belo Horizonte, MG, Brazil. http://www.bibliotecadigital.ufmg.br

Walker, D. M., Castlebury, L. A., Rossman, A. Y., Sogonov, M. V., and White, J. F. 2010. Systematics of genus Gnomoniopsis (Gnomoniaceae, Diaporthales) based on a three gene phylogeny, host associations and morphology. Mycologia 102:1479-1496

Walker, D. M., Castlebury, L. A., Rossman, A. Y., and White, J. F., Jr. 2012. New molecular markers for fungal phylogenetics: Two genes for species-level systematics in the Sordariomycetes (Ascomycota). Mol. Phylogenet. Evol. 64:500-512.

White, T. J., Bruns, T. D., Lee, S., and Taylor, J. 1990. Amplification and direct sequencing of fungal ribosomal RNA genes for phylogenetics. Pages 315-322 in: PCR Protocols: A Guide to Methods and Applications. M. A. Innis, D. H. Gelfand, J. J. Sninsky, and T. J. White, eds. Academic Press, San Diego, CA. 